\title{
ZS Research Square \\ Elimination of [PSI+] Prion and Influence on Yeast Cell Growth
}

Justina Versockienè ( $\nabla$ justina.versockiene@gmc.vu.It)

Vilnius University

Neda Jonutytè-Trembo

Vilnius University

Vitalij Novickij

Vilnius Gediminas Technical University

Eglè Lastauskienè

Vilnius University

\section{Research Article}

Keywords: PSI prion, yeast prions, prion variants, prion elimination, $\mathrm{GuHCl}$, pulses electric field, growth dynamics

Posted Date: January 6th, 2022

DOI: https://doi.org/10.21203/rs.3.rs-1181672/v1

License: (1) (1) This work is licensed under a Creative Commons Attribution 4.0 International License. Read Full License 


\section{Abstract \\ Background}

Prions are proteinaceous infectious particles that act as pathogens and cause the development of lethal neurodegenerative diseases in humans and other animals. Yeast Saccharomyces cerevisiae is a widespread model system in which mechanisms of prion induction and elimination have been identified. New and safe substances and methods are being sought to cure cells of prion proteins. It is particularly important that by treating cells from prions and restoring them from the $\left[P S I^{+}\right]$to the $\left[\mathrm{psi}^{-}\right]$form, the primary growth of the cells is restored. One of the main objectives of this study was to determine the growth dynamics of $S$. cerevisiae cells with different $\left[\mathrm{PSI}^{+}\right]$prion variants, cells that have lost $\left[\mathrm{PSI}^{+}\right]$prion variants, and cells that never had $\left[P S I^{+}\right]$prion variants.

\section{Results}

In this research, we applied GuHCl and combined GuHCl and PEF treatment against $\left[\mathrm{PSI}^{+}\right]$prion. We evaluated cells culture growth dynamics - optical density and doubling time and determined that method of $\left[\mathrm{PS}^{+}\right]$prion elimination does not affect cell doubling time. Also, we found that both elimination methods affect the optical density reached by $\left[p s i^{-}\right]$cells. However, the cells in which the $\left[\mathrm{PSI}^{+}\right]$prion has been eliminated by $\mathrm{GuHCl}$ alone are able to reach the same optical density as unaffected [psi $i^{-}$cells and higher optical density than the affected [psi-] cells by $\mathrm{GuHCl}$ alone.

\section{Conclusions}

These findings indicate the potential long-term positive effect of $\left[\mathrm{PSI}^{+}\right]$prion on cell growth, which persists after $\left[P S I^{+}\right]$removal.

\section{Background}

Prions are proteinaceous infectious particles that act as pathogens and cause the development of lethal neurodegenerative diseases in humans and other animals [1]. Prions, unlike other pathogens such as bacteria, viruses, or fungi, are composed of proteins and do not contain nucleic acids. These proteins tend to aggregate and are particularly resistant to a variety of physical, chemical, and biological agents [2]. Due to these unique properties of prions, they are actively studied. Prion protein studies in humans or other mammals are severely hampered by long disease latencies (7-40 years) [3], reproductive time, ethics, and other issues. Therefore, model systems of lower eukaryotes are often used. Yeast Saccharomyces cerevisiae is a widespread model system in which protein structures, functions, and interactions are studied, and can be compared to higher eukaryotic systems due to the high conservatism of biological mechanisms [4]. Mechanisms of prion induction, propagation, aggregates formation, 
elimination, and interactions of different prion proteins, have been identified in the yeast model system [5].

At least 10 prion proteins have been identified in S. cerevisiae cells [6-16], including the [PSI+ ${ }^{+}$prion, which has been known for more than two decades and is still under intense research [17]. The altered structure of the Sup35 protein leads to protein aggregation and the emergence of the $\left[\mathrm{PSI}^{+}\right]$phenotype [18]. The native Sup35 protein is involved in translation termination. Also, it has GTPase activity and is one of the subunits of the translation termination factor. Sup35 together with the Sup45 protein form a translation termination factor complex that recognizes STOP codons in the ribosome (responsible Sup45 subunit) and catalyzes the isolation of the synthesized polypeptide by GTP hydrolysis (responsible Sup35 subunit) [19]. The Sup35 protein is encoded by the SUP35 gene of 2058 base pairs in length, but a mutation in the SUP35 gene is not required for $\left[\mathrm{PSI}^{+}\right]$to occur, so $\left[\mathrm{PSI}^{+}\right]$acts as an epigenetic element that alters only the cell phenotype [20]. Complete loss of function of Sup35 protein is known to be lethal to yeast cells, but a significant decrease in Sup35 protein function is tolerated and $S$. cerevisiae cells can survive [18].

Different prion states were identified in both mammalian and yeast cells and were named prion variants. These variants may form distinct phenotypes that differ in prion protein stability and frequency of spontaneous occurrence in mammals, as well as prion protein and mitotic stability and treatment efficacy in yeast [21]. It is becoming increasingly important to distinguish such prion variants because they can cause pathologically distinct infectious diseases in animals [22].

In the yeast system, the $\left[\mathrm{PSI}^{+}\right]$prion can form at least two different variants. Different ratios of aggregated and soluble Sup35 protein are found in different $\left[P S I^{+}\right]$variants, leading to suppression of STOP codons of different potency [23]. This phenomenon is well illustrated by the nonsense ade1-14 mutation, which has a premature termination codon in S. cerevisiae cells. The truncated Ade1 protein is expressed at efficient translation termination, i.e., at a low fraction of aggregated Sup35. In this case, the cells accumulate an intermediate product of metabolism - the red pigment. Alternatively, in the presence of a large proportion of the aggregated Sup35p protein the STOP codons are omitted and the complete Ade1 protein is synthesized. Such cells remain white. Cells with a pink and white phenotype were named weak and strong prion variants, respectively [24]. Knowing that different prion variants can lead to the formation of different phenotypes, it becomes necessary to find out whether these phenotypic differences persist after curing cells of different prion variants.

Research on prion elimination is being carried out intensively. New and safe substances and methods are being sought to cure cells of prion proteins [25]. The goal of most of these studies is to obtain the highest possible cure efficiency and the lowest probability of recurrence of the prion protein. Guanidine hydrochloride $(\mathrm{GuHCl})$ is a chemical compound commonly used to eliminate prions in yeast cells. At low concentrations of GuHCl, ATPase activity of Hsp104 protein is known to be attenuated in vitro [26;27]. Hsp104 is essential for the fragmentation and proliferation of amyloid fibrils, while decreased activity of this protein results in the formation of long fibrils that can no longer enter the daughter cells [5]. In 
addition to prion elimination, physical factors such as the pulsed electric field (PEF) can be used [28]. Prion proteins do not affect traditional protein degradation agents such as proteases, heat, acids, and so on [29], and the formation of prion proteins is mainly influenced by various electrostatic interactions [30], so it is likely that PEF may increase the efficacy of treatment against $\left[P S I^{+}\right]$.

The intracellular soluble/insoluble protein ratio changes in $\left[\mathrm{PSI}^{\dagger}\right]$ cells because $\left[\mathrm{PSI}^{+}\right]$cells tend to accumulate longer, insoluble proteins. This results in the activation of heat shock and other stress response proteins. In this case, the molecular response pathways to stress are rearranged in the $\left[\mathrm{PSI}^{+}\right]$ cell, which strongly affects cell growth [31]. It is particularly important that by treating cells from prions and restoring them from the $\left[\mathrm{PSI}^{+}\right]$to the $\left[\mathrm{psi}^{-}\right]$form, the primary growth of the cells is restored. This would help to understand whether the formation of a prion leads to the occurrence of irreversible changes in the cell.

\section{Results}

\section{Prionisation}

After prion induction, cell colonies containing weak and strong prion variants were isolated (Additional file: Tabe 1). Cell colonies were sorted by diameter - up to $3 \mathrm{~mm}$ and more than $3 \mathrm{~mm}$. In the group of up to $3 \mathrm{~mm}$, the color of the colonies was approximately evenly distributed $-46.68 \pm 2.14 \%$ pink colonies, and $53 \pm 2.14 \%$ white colonies (Figure 1 ).

On the other hand, in a group of more than $3 \mathrm{~mm}$, the white color of the colonies was dominant $77.22 \pm$ $5.43 \%$ while the pink colonies were detected in $22.78 \pm 5.43 \%$ (Additional file: Tabe 2 ). For further work two different cell cultures were used: pink colonies up to $3 \mathrm{~mm}$ in diameter were used as weak $\left[P S I^{+}\right]$ variant $\left(\left[P S{ }^{+}\right]-\mathrm{w}\right)$ and white colonies more than $3 \mathrm{~mm}$ in diameter were used as strong $\left[P S{ }^{+}\right]$variant $\left(\left[P S I^{+}\right]-s\right)$.

The $p$-value determined by the Chi-squared test is $p<0.05$, therefore the statistically reliable relationship between colony size and its color phenotype was determined (Additional file: Table 3). Thus, different variants of the $\left[\mathrm{PSI}^{+}\right]$prion can be distinguished not only by the color of the colony but also by the size of the colony.

\section{Prion Elimination Efficiency}

Weak and strong prion variants were eliminated by $\mathrm{GuHCl}$ or $\mathrm{GuHCl}$ and PEF. Weak $\left[\mathrm{PSI}^{+}\right]$prion elimination efficiency was higher than strong $\left[\mathrm{PSI}^{+}\right]$prion elimination efficiency. When $\mathrm{GuHCl}$ alone was used as a prion elimination agent, the weak $\left[\mathrm{PSI}^{+}\right]$prion variant was eliminated in $62.55 \pm 8.52 \%$ of cells (Additional file 2: Table 1), while the strong $\left[P S I^{+}\right]$prion variant was eliminated in $35.63 \pm 5.73 \%$ of cells (Figure 2) (Additional file 2: Table 2). 
The weak $\left[\mathrm{PSI}^{+}\right]$prion variant was eliminated with similar efficiency using both $\mathrm{GuHCl}$ alone and the combination of $\mathrm{GuHCl}$ and PEF $(65.2 \pm 11.03 \%)$. There is no statistically significant difference between the effect of the elimination methods used on the removal of the weak $\left[P S I^{\prime}\right]$ prion $(p>0.05)$ (Additional file 2: Table 3). However, by eliminating the strong $\left[\mathrm{PSI}^{+}\right]$prion variant, the opposite results were obtained - the strong $\left[\mathrm{PSI}^{+}\right]$prion variant was successfully eliminated using $\mathrm{GuHCl}$ alone $(33.63 \pm 5.73 \%)$, but elimination was not successful with the combination of $\mathrm{GuHCl}$ and PEF $(0 \%)$. In this case, a statistically reliable difference between the efficiency of the methods used was obtained $(p<0.05)$ (Additional file 2: Table 4).

\section{Cell Growth Dynamics}

A study of cell growth dynamics was conducted. The growth of the cells with a weak prion variant and the cells eliminated from this variant is shown in Figure 3. (Additional file 3: Tables 1-3, 6).

The highest optical density was reached by the cells containing a weak prion variant $-8.22 \pm 0.48$ (at 45 h). Neither the cells eliminated from the weak prion nor the cells without the $\left[P S I^{+}\right]$prion reached the same high optical density as the cells containing the weak $\left[P S I^{+}\right]$variant. When comparing the growth of the cells eliminated from weak $\left[\mathrm{PSI}^{+}\right]$prion by different methods, it was observed that the cells treated with GuHCl alone reach statistically significantly $(p<0.05)$ higher OD $(6.94 \pm 0.32$ at $48 \mathrm{~h})$ than the cells treated with the combined method $-\mathrm{GuHCl}$ and PEF $-5.87 \pm 0.33$ (at $48 \mathrm{~h}$ ) (Additional file 3: Table 9). For the cells that have never had a $\left[\mathrm{PSI}^{+}\right]$prion the highest reached OD was $7.11 \pm 0.01$ (at $48 \mathrm{~h}$ ), this value is similar to the cells in which the weak $\left[\mathrm{PSI}^{\prime}\right]$ prion variant was eliminated using $\mathrm{GuHCl}$ alone $(\mathrm{p}>$ 0.05) (Additional file 3: Table 10).

The growth of the cells with a strong prion variant and the cells eliminated from this variant is shown in Figure 4 (Additional file 3: Tables 4-6).

The highest optical density was reached by the cells containing a strong prion variant $-8.88 \pm 0.77$ (at $48 \mathrm{~h}$ ). Neither the cells eliminated from the strong prion nor the cells without the $\left[P S I^{+}\right]$prion reached the same high optical density as the cells containing the strong $\left[{ }^{\left[P S I^{+}\right]}\right.$variant. Comparing the growth of cells eliminated from strong $\left[\mathrm{PSI}^{+}\right]$prion by $\mathrm{GuHCl}$ alone and the cells that never had $\left[\mathrm{PSI}^{+}\right]$prion, the highest reached optical density is statistically $(p>0.05)$ (Additional file 3: Table 11). similar $-7.08 \pm 0.42$ and $7.11 \pm 0.01$ (both at $48 \mathrm{~h}$ ) respectively.

There was a tendency for both weak and strong prions - the $\left[P S{ }^{+}\right]$cells reached higher OD compared to the cells eliminated from $\left[\mathrm{PSI}^{+}\right]$prion and the cells that have never had a $\left[\mathrm{PSI}^{+}\right]$prion. Also, it was observed that the cells can reach similar OD as the unaffected cells that have never had a $\left[P S I^{+}\right]$prion by using $\mathrm{GuHCl}$ alone as the elimination method. On the other hand, the cells in which a weak $\left[P S I^{+}\right]$variant was eliminated by a combination of GuHCl and PEF methods no longer reach the same OD as the cells that have never had a $\left[\mathrm{PSI}^{+}\right]$prion. 
An additional study was performed: the cells that never had a $\left[P S I^{+}\right]$prion were exposed to both elimination methods. The highest OD was reached by the cells that were not exposed to any of the elimination methods $-7.11 \pm 0.01$ (at 48 hours) (Figure 5) (Additional file 3: Tables 6-8).

Neither the cells affected by $\mathrm{GuHCl}$ alone nor the cells affected by combined treatment of $\mathrm{GuHCl}$ and PEF reached the same high optical density as the unaffected cells. These differences are statistically significant $(p<0.05)$ (Additional file 3: Table 12,13). The cells affected by $\mathrm{GuHCl}$ alone reached a maximum OD of $6.56 \pm 0.1$ (at $48 \mathrm{~h}$ ) while the cells affected by combined treatment of GuHCl and PEF reached a maximum of $4.93 \pm 0.05$ (at $48 \mathrm{~h}$ ). With $\mathrm{GuHCl}$ alone, the optical density of the cells was reduced 1.08 -fold, while with the combined elimination method, the optical density of the cells was reduced 1.44 -fold.

\section{Cell Doubling Time}

Cell doubling time indicates the time by which the cell doubles in number. Cell doubling time was calculated based on the growth curves presented above. The following results indicate the doubling time in the exponential phase of cell growth. The doubling time of the cells that have never had a $\left[\mathrm{PSI}^{+}\right]$prion was $1.83 \pm 0.07$ hours (Figure 6A-C, represented as a red solid bar) (Additional file 4: Tables 1-8).

The cells containing weak $\left[\mathrm{PSI}^{+}\right]$prion doubled within $1.81 \pm 0.08$ hours (similar to $\left[p s i^{-}\right]$), while the cells eliminated from the weak $\left[\mathrm{PSI}^{+}\right]$prion doubled within $1.72 \pm 0.04$ hours (affected by GuHCl) and $1.91 \pm$ 0.09 hours (affected by $\mathrm{GuHCl}$ and PEF) (Figure 6A). The cells that were eliminated from the weak [PSI $\left.{ }^{+}\right]$ prion using $\mathrm{GuHCl}$ alone grew statistically significantly faster $(\mathrm{p}<0.05)$ compared to the cells in which the weak $\left[\mathrm{PSI}^{+}\right]$prion was eliminated by $\mathrm{GuHCl}$ and PEF (Additional file 4: Table 9). On the other hand, no statistically significant differences $(p>0.05)$ were found when comparing the doubling time of the cells that never had $\left[\mathrm{PSI}^{+}\right]$prion and the cells that lost weak $\left[\mathrm{PSI}^{+}\right]$prion variant (by both methods) (Additional file 4: Table 10, 11).

The cells containing strong $\left[P S I^{+}\right]$prion doubled within $1.63 \pm 0.07$ hours, while the cells eliminated from strong $\left[\mathrm{PSI}^{+}\right]$prion doubled within $1.71 \pm 0.06$ hours (affected by $\mathrm{GuHCl}$ ) (Figure 6B). No statistically significant differences $(p>0.05)$ were found when comparing the doubling time of the cells that never had $\left[\mathrm{PSI}^{+}\right]$prion and the cells that lost strong $\left[\mathrm{PSI}^{+}\right]$prion variant by $\mathrm{GuHCl}$ (Additional file 4: Table 12).

The doubling time of the cells that never had $\left[\mathrm{PSI}^{+}\right]$prion but were affected by elimination factors were $1.85 \pm 0.09$ hours (affected by GuHCl) and $1.99 \pm 0.05$ hours (affected by GuHCl and PEF) (Figure 6C). Although, the difference between the doubling time of the unaffected cells that never had $\left[\mathrm{PSI}^{+}\right]$prion and the affected cells that never had $\left[\mathrm{PSI}^{+}\right]$prion increased by $0.02(\mathrm{GuHCl})$ and $0.16(\mathrm{GuHCl}$ and PEF) hours, however no statistically significant differences $(p>0.05)$ were found (Additional file 4: Table 13,14). Thus, the method of treatment does not affect the cell doubling time. 


\section{Discussion}

S. cerevisiae has become a widely used tool for the discovery of new drugs and their mechanisms of action. S. cerevisiae is an excellent tool for modeling protein aggregation that facilitates the study of amyloid or prion diseases in humans or other animals. One of the longest known and studied yeast prions - $\left[P S I^{+}\right]$- has become a tool for the identification of antiprionic compounds [25]. Developed red/white colorimetric assay allows easy separation of the cells without $\left[P S I^{+}\right]$prion from the cells with $\left[\mathrm{PSI}^{+}\right]$prion. In addition, this assay makes it easy to distinguish the different prion variants by the cell phenotype [23].

In this study, we showed that $\left[\mathrm{PSI}^{+}\right]$prion variants can be distinguished not only by colorimetric analysis but also by another phenotypic trait - the size of the cell colony. We found a correlation $(p<0.05)$ between cell colony color and colony size - cells containing strong $\left[\mathrm{PSI}^{+}\right]$prion variant form larger colonies (more than $3 \mathrm{~mm}$ in diameter), while cells containing weak $\left[P S I^{+}\right]$prion variant form smaller colonies (up to $3 \mathrm{~mm}$ in diameter).

Strong $\left[\mathrm{PSI}^{+}\right]$prion variants may form larger colonies due to effective nonsense suppression [32]. Using two parameters, the weak and strong $\left[\mathrm{PSI}^{+}\right]$prions could be distinguished even more accurately.

Selected weak and strong $\left[\mathrm{PSI}^{+}\right]$prion variants were eliminated using the classical elimination agent $\mathrm{GuHCl}$. $\left[\mathrm{PSI}^{+}\right]$prion was also attempted to be eliminated by combining GuHCl and PEF. PEF could act in two ways: 1) it creates pores in the cell wall through which $\mathrm{GuHCl}$ can more easily enter the cell [33]; 2) it acts on the electrostatic interactions of proteins, thus attempting to destabilize $\left[P S I^{+}\right]$prion aggregates [30]. Although no statistically significant change in the elimination of weak $\left[P \mathrm{PS}^{\prime}\right]$ prion was observed with the combined elimination method, elimination of strong $\left[P S I^{+}\right]$prion did not occur. The results obtained could be explained by differences in the protein structure of different $\left[\mathrm{PSI}^{+}\right]$prion variants. Biophysical studies have found that $\left[\mathrm{PS}^{+}\right]$amyloid fibrils, which result in different biological phenotypes, have clearly defined biophysical properties and conformations. Using electron microscopy, the strong $\left[P S I^{+}\right]$variant was found to form a thinner structure and the weak $\left[P S I^{+}\right]$variant to form fibrils with a thicker structure. Strong $\left[\mathrm{PSI}^{\prime}\right]$ prions are thermodynamically unstable and can be easily fragmented, resulting in easy propagation. [34]. Thus, PEF was able to specifically affect (e.g., fragment) the fibrils of the strong, but not the weak, $\left[\mathrm{PSI}^{+}\right]$prion variant, therefore smaller fibril fragments easily entered the daughter cells and the aggregated Sup35 state was preserved.

The main scientific question in this study was whether cells, which were eliminated from $\left[\mathrm{PSI}^{+}\right]$prion, could grow like they never had one. For this purpose, the cell growth dynamics were observed by assessing both the doubling time of the cells in the exponential growth phase and the optical density of the cells reached in the stationary growth phase. The evaluation of a cell doubling time showed how fast the cells grew. No statistically significant changes were observed, both the [psi-] cells treated with different elimination methods and the cells with eliminated different prion variants doubled at similar ( $p$ > 
$0.05)$ time as the unaffected cells that never had $\left[P S I^{+}\right]$prion. Neither the elimination methods nor the previous presence of the $\left[\mathrm{PS}^{+}\right]$prion in the cell affects the rate of cells doubling time.

Evaluation of the reached optical density. It was observed that by using $\mathrm{GuHCl}$ alone as the elimination method, the cells eliminated from the $\left[\mathrm{PSI}^{+}\right]$prion can reach similar OD as the cells that have never had a $\left[P S I^{+}\right]$prion. On the other hand, the combined $\mathrm{GuHCl}$ and PEF method in eliminating the weak $\left[\mathrm{PSI}^{+}\right]$ variant may affect a cell's growth because the cells no longer reach the same OD as the cells that have never had a $\left[\mathrm{PSI}^{+}\right]$prion. To investigate whether the elimination method or consequences of the eliminated $\left[\mathrm{PSI}^{+}\right]$prion may affect a cell growth, an additional study was performed: the cells that never had a $\left[\mathrm{PSI}^{+}\right]$prion were exposed to both elimination methods. Neither the cells affected by $\mathrm{GuHCl}$ alone nor the cells affected by combined treatment of GuHCl and PEF reached the same optical density as the unaffected $\left[p i^{-}\right]$cells $(p<0.05)$. On the other hand, the cells that have had $\left[P S I^{+}\right]$prion and lost it by $\mathrm{GuHCl}$ alone can reach the same optical density as the unaffected [psi] cells (in both cases, weak and strong $\left[P S I^{+}\right]$prion variant).

The question of why the cells in which the $\left[\mathrm{PS}^{\dagger}\right]$ prion has been eliminated may avoid the effects of elimination factors and reach the same optical density as unaffected cells that never had $\left[P S I^{+}\right]$prion remains unclear. This suggests that the previous presence of $\left[\mathrm{PSI}^{+}\right]$prion in the cell may have made changes that allowed these cells to reach the same optical density. It is known that suppression of STOP codons results in the synthesis of altered proteins. Proteins longer than the wild-type are usually synthesized - the STOP codon is changed to an amino acid, or the reading frame is shifted - in both cases the translation is extended. Newly synthesized proteins may be dysfunctional, unstable, or altered in function. When such proteins begin to accumulate in cells, the $\left[P S I^{+}\right]$phenotype loses any hypothetical advantage [18;35]. On the other hand, this research has shown that certain benefits of $\left[P S I^{+}\right]$to the $S$. cerevisiae yeasts may exist.

\section{Conclusions}

In summary, this study has shown for the first time that the prion variant in the cell can be distinguished not only by the color of the cell colony being formed but also by the cell colony size. Also, the $\left[\mathrm{PSI}^{+}\right]$prion elimination efficiency by electroporation has not been shown to increase, whereas in the case of the strong $\left[\mathrm{PSI}^{+}\right]$prion variant, it decreases. The cells growth study showed that neither the elimination method nor the previous presence of the $\left[\mathrm{PSI}^{+}\right]$prion affected the doubling time of the cells in the exponential growth phase. However, we found that the elimination method reduced the reachable optical density of the $\left[\mathrm{psi}^{-}\right]$cells in the stacionary growth phase. On the other hand, the cells eliminated from the $\left[P S I^{+}\right]$prion were able to reach unreduced optical density in the stationary phase, indicating a possible long-term positive effect of the $\left[\mathrm{PSI}^{+}\right]$prion on the cells growth, which persists after $\left[\mathrm{PSI}^{+}\right]$removal.

\section{Materials And Methods}


The aim of this study is to determine the growth dynamics of $S$. cerevisiae cells with different $\left[\mathrm{PSI}^{+}\right]$prion variants, cells that have lost $\left[\mathrm{PSI}^{+}\right]$prion variants, and cells that never had $\left[P S I^{+}\right]$prion variants. To achieve this goal, induction of $\left[\mathrm{PSI}^{+}\right]$prion was performed in yeast cells and cells with different $\left[\mathrm{PS}^{+}\right]$prion variants were isolated. $\left[\mathrm{PSI}^{+}\right]$prion was eliminated from these cells. Both prionized and prion-eliminated cells were grown and evaluated for their reached optical density and doubling time. Yeast cells that never had $\left[\mathrm{PSI}^{+}\right]$prion were used as a control group.

\section{Yeast Strain S. cerevisiae 74-D694 [psi-][PIN']}

S. cerevisiae74-D694 strain (MATa, ade1-14 (UGA), trp1-289, his3-4200, ura3-52, leu2-3,112) was used in our research [36]. Thus, this strain can not de novo produce adenine, tryptophan, histidine, uracil, and leucine-these amino acids must be present in the culture medium. ADE1 mutant phenotypes allow the discrimination of the cells without prions or containing strong or weak prions by the color of the colonies (Figure 7).

Phenotypes that were used in this research are listed in Table 1.

Table 1

S. cerevisiae 74-D694 phenotypes.

\begin{tabular}{|c|c|c|}
\hline Abbreviation & Phenotype & Source \\
\hline$\left[p s i^{-}\right]$ & S. cerevisiae 74-D694 [psi- $]\left[P^{\prime} N^{+}\right]$ & $\begin{array}{l}\text { Gift from Yury } \\
\text { Chernoff }\end{array}$ \\
\hline$\left[P S I^{+}\right]-\mathrm{w}$ & S. cerevisiae 74-D694 $\left[P S I^{+}\right]\left[P I N^{+}\right]$weak & This work \\
\hline$\left[P S I^{+}\right]-\mathrm{s}$ & S. cerevisiae 74-D694 $\left[P S I^{+}\right]\left[P I N^{+}\right]$strong & This work \\
\hline$\left[p s i i^{-}\right]-\mathrm{G}$ & S. cerevisiae 74-D694 [psi- $]\left[\mathrm{PIN}^{+}\right]$affected with $\mathrm{GuHCl}$ & This work \\
\hline [psi']-GP & $\begin{array}{l}\text { S. cerevisiae 74-D694 [psi- }]\left[\mathrm{PIN}^{+}\right] \text {affected with } \mathrm{GuHCl} \text { and } \\
\mathrm{PEF}\end{array}$ & This work \\
\hline$\left[p s i^{-}\right]-\mathrm{w}-\mathrm{G}$ & S. cerevisiae 74-D694 $\left[p s i^{-}\right]\left[P^{\prime} N^{+}\right]$weak eliminated with $\mathrm{GuHCl}$ & This work \\
\hline$\left[p s i^{-}\right]-w-G P$ & $\begin{array}{l}\text { S. cerevisiae 74-D694 }\left[p s i^{-}\right]\left[P^{\prime} N^{+}\right] \text {weak eliminated with } \mathrm{GuHCl} \\
\text { and PEF }\end{array}$ & This work \\
\hline$\left[p s i^{-}\right]-\mathrm{s}-\mathrm{G}$ & $\begin{array}{l}\text { S. cerevisiae 74-D694 }\left[\text { psi }^{-}\right]\left[\mathrm{PIN}^{+}\right] \text {strong eliminated with } \\
\text { GuHCl and PEF }\end{array}$ & This work \\
\hline
\end{tabular}




\section{Spontaneous prion induction and selection of different prion variants}

S. cerevisiae $\left[\mathrm{psi}^{-}\right]$cells were plated on an agarized YPD medium (containing $2 \%$ glucose, $2 \%$ peptone, $1 \%$ yeast extract, $2 \%$ agar) and grown for $72 \mathrm{~h}$ at $30^{\circ} \mathrm{C}$. One colony of the culture was then transferred to 5 $\mathrm{mL}$ of fresh YPD medium and grown overnight $(\sim 12 \mathrm{~h})$ at $30^{\circ} \mathrm{C}$ with aeration, at $130 \mathrm{rpm}$. Overnight culture was washed with distilled water and $10^{7}$ cells were plated on an agarized SC medium (containing $2 \%$ glucose, $0.67 \%$ yeast nitrogen base without amino acids, $2 \%$ agar, and supplemented with the appropriate amino and nucleic acids according to the genotype of the strains, except adenine) and grown for 21 days at $30^{\circ} \mathrm{C}$. Grown colonies ( $400 \mathrm{CFU}$ ) were analyzed by diameter, then transferred to plates with agarized $1 / 4$ YPD medium (the same as YPD, but with a reduced amount of yeast extract $-0.25 \%$ ) and were analyzed by colony color - according to these two criteria weak and strong prion variants $-\left[P S I^{+}\right]-\mathrm{w}$, and $\left[P S I^{+}\right]-s$ - were distinguished.

\section{Prion elimination}

S. cerevisiae $\left[\mathrm{psi}^{-}\right],\left[\mathrm{PSI}^{+}\right]-\mathrm{w}$, and $\left[\mathrm{PSI}^{+}\right]-\mathrm{s}$ cells were plated on agarized YPD medium and grown for $48-72$ $\mathrm{h}$ at $30^{\circ} \mathrm{C}$. One colony of the respective culture was then transferred to $5 \mathrm{~mL}$ of fresh YPD medium and grown overnight $(\sim 12 \mathrm{~h})$ at $30^{\circ} \mathrm{C}$ with aeration, at $130 \mathrm{rpm}$. The overnight culture was transferred to 50 $\mathrm{mL}$ of fresh YPD medium containing $5 \mathrm{mM} \mathrm{GuHCl}$ to the final optic density (OD) of $0.06 \mathrm{AU}$ at a $600 \mathrm{~nm}$ wavelength and grown for 35 hours, at $30^{\circ} \mathrm{C}$ with aeration, at $130 \mathrm{rpm}$. Part of the cells was exposed to a pulsed electric field (PEF) at $10 \mathrm{kV} / \mathrm{cm}, 5 \cdot 1 \mathrm{~ms}$, electroporation parameters were selected according to cell viability tested before [28]. The $1 \mathrm{kV}$ pulses were generated in a $1 \mathrm{~mm}$ gap aluminum cuvette (Biorad, Hercules, CA, USA), resulting in $10 \mathrm{kV} / \mathrm{cm}$ electric field. Both affected and unaffected cells were plated on agarized YPD medium (for 72 hours) and then transferred to $\mathrm{SC}^{\mathrm{ADE}-}$ medium (for 72 hours) to confirm the presence or absence of $\left[\mathrm{PSI}^{+}\right]$prion. Only red color colonies on YPD medium that do not grow on $\mathrm{SC}^{\mathrm{ADE}-}$ were selected:

1) $\left[p s i^{-}\right]$cured with GuHCl ([psi-]-G);

2) $\left[p s i^{-}\right]$cured with GuHCl and PEF ([psi-]-GP);

3) $\left[\mathrm{PSI}^{+}\right]$weak cured with $\mathrm{GuHCl}\left(\left[\mathrm{psi}^{-}\right]-\mathrm{w}-\mathrm{G}\right)$;

4) $\left[\mathrm{PSI}^{+}\right]$weak cured with $\mathrm{GuHCl}$ and PEF ([psi $\left.\left.{ }^{-}\right]-\mathrm{w}-\mathrm{GP}\right)$;

5) $\left[P S I^{+}\right]$strong cured with $\mathrm{GuHCl}\left(\left[p \mathrm{pi}^{-}\right]-\mathrm{s}-\mathrm{G}\right)$;

Prion elimination efficiency is referred to as the percentage of [ $\left.\mathrm{psi}^{-}\right]$cells out of all grown cells. 


\section{Cell growth dynamics}

S. cerevisiae cells variants listed in Table 1 were plated on agarized YPD medium and grown for $48 \mathrm{~h}$ at $30^{\circ} \mathrm{C}$. One colony of the respective culture was then transferred to $5 \mathrm{~mL}$ of fresh $1 / 4 \mathrm{YPD}$ medium and grown overnight $(\sim 12 \mathrm{~h})$ at $30^{\circ} \mathrm{C}$ with aeration, at $130 \mathrm{rpm}$. The overnight culture was transferred to 50 $\mathrm{mL}$ of fresh YPD medium to the final optic density (OD) of $0.06 \mathrm{AU}$ at a $600 \mathrm{~nm}$ wavelength. Culture samples were taken every $3 \mathrm{~h}$ and cells growth was measured with a biophotometer (Eppendorf, Germany). Growth dynamics were observed until the culture reached the stationary growth phase. After growth, cells were plated on an agarized YPD medium to verify that their phenotype ([PSI] status) had not changed. All the experiments were repeated independently 3 times.

Growth rate $(g r)$ and doubling time $(D T)$ :

The growth rate $(g r)$ was calculated using the following formula:

$$
g r=\frac{\ln \left(\frac{N(t)}{N(0)}\right)}{t}
$$

$\mathrm{N}(\mathrm{t})$ - number of cells at time $\mathrm{t}$;

$\mathrm{N}(0)$ - number of cells at time 0 ;

$\mathrm{t}$ - time, h.

The doubling time $(D T)$ was calculated using the following formula:

$$
D T=\frac{\ln (2)}{g r}
$$

gr-growth rate

Calculations applied according to J. Vandermeer [37].

\section{Statistical Analysis}

At least 3 independent experimental sessions were performed for each unique set of parameters. Statistical analysis was performed for all acquired data. The Chi-squared test and one-tailed t-test were used to estimate the statistical significance. The results were considered statistically significant at $\mathrm{p}<$ 0.05 .

\section{Declarations}




\section{Ethics approval and consent to participate}

Not applicable

\section{Consent for publication}

Not applicable

\section{Availability of data and materials}

All data generated or analysed during this study are included in this published article and its supplementary information files.

\section{Competing interests}

The authors declare no conflict of interest.

\section{Funding}

This research was funded by the European Social Fund under the No 09.3.3-LMT-K-712 “Development of Competences of Scientists, other Researchers and Students through Practical Research Activities" measure, Grant No. 09.3.3.-LMT-K-712-16-0231 under grant agreement with the Research Council of Lithuania (LMTLT).

\section{Authors' contributions}

JV and NJT conducted the experiments and analyzed data. VN constructed the PEF generator and adaptated for experiments. EL supervised the research, acquiesced resource, methodology, adaptated experiments. JV wrote original draft, NJT, VN and EL reviewed and edited. All authors read and approved the final manuscript.

\section{Acknowledgments}

The authors would like to thank Yury Chernoff for his valuable support with S. cerevisiae 74-D694 [psi] $\left[P I N^{+}\right]$strain.

\section{References}

1. Mead S. Prion disease genetics. Eur J Hum Genet. 2006,14(3):273-81.

2. Okamoto M, Furuoka H, Horiuchi M, Noguchi T, Hagiwara K, Muramatsu Y, Tomonaga K, Tsuji M, Ishihara C, Ikuta K, Taniyama H. Experimental transmission of abnormal prion protein (PrPsc) in the small intestinal epithelial cells of neonatal mice. Vet Pathol. 2003,40(6):723-7.

3. Soto C, Saborio GP, Anderes L. Cyclic amplification of protein misfolding: application to prion-related disorders and beyond. Trends Neurosci. 2002,25(8):390-4. 
4. Castrillo JI, Oliver SG, editors.Yeast System Biology: The Challenge of Eukaryotic Complexity. In: Yeast Systems Biology. UK: Humana Press, 2011.

5. Wickner RB, Edskes HK, Gorkovskiy A, Bezsonov EE, Stroobant EE. Yeast and Fungal Prions: AmyloidHandling Systems, Amyloid Structure, and Prion Biology. In: Friedmann T, Dunlap JC, Goodwin SF, editors. Advances in Genetics. 1st ed. USA: Academic Press. 2016.

6. Wickner RB. [URE3] as an altered URE2 protein: evidence for a prion analog in Saccharomyces cerevisiae. Science. 1994,264(5158):566-9.

7. Derkatch IL, Bradley ME, Masse SV, Zadorsky SP, Polozkov GV, Inge-Vechtomov SG, Liebman SW. Dependence and independence of [PSI+] and [PIN+]: a two-prion system in yeast?. The EMBO journal. 2000,19(9):1942-52.

8. McColl IH, Blanch EW, Gill AC, Rhie AG, Ritchie MA, Hecht L, Nielsen K, Barron LD. A new perspective on $\beta$-sheet structures using vibrational Raman optical activity: from poly (L-lysine) to the prion protein. Journal of the American Chemical Society. 2003,125(33):10019-26.

9. Du Z, Park KW, Yu H, Fan Q, Li L. Newly identified prion linked to the chromatin-remodeling factor Swi1 in Saccharomyces cerevisiae. Nature genetics. 2008,40(4):460-5.

10. Patel BK, Gavin-Smyth J, Liebman SW. The yeast global transcriptional co-repressor protein Cyc8 can propagate as a prion. Nature cell biology. 2009,11(3):344-9.

11. Alberti S, Halfmann R, King O, Kapila A, Lindquist S. A systematic survey identifies prions and illuminates sequence features of prionogenic proteins. Cell. 2009,137(1):146-58.

12. Brown JC, Lindquist $\mathrm{S}$. A heritable switch in carbon source utilization driven by an unusual yeast prion. Genes \& development. 2009,23(19):2320-32.

13. Rogoza T, Goginashvili A, Rodionova S, Ivanov M, Viktorovskaya O, Rubel A, Volkov K, Mironova L. Non-Mendelian determinant [ISP+] in yeast is a nuclear-residing prion form of the global transcriptional regulator Sfp1. Proceedings of the National Academy of Sciences. 2010,107(23):10573-7.

14. Suzuki G, Tanaka M. Expanding the yeast prion world: active prion conversion of nonglutamine/asparagine-rich Mod5 for cell survival. Prion. 2013,7(2):109-13.

15. Halfmann R, Wright JR, Alberti S, Lindquist S, Rexach M. Prion formation by a yeast GLFG nucleoporin. Prion. 2012,6(4):391-9.

16. Parfenova I, Barral Y. Yeast sporulation and [SMAUG+] prion: faster is not always better. Molecular cell. 2020,77(2):203-4.

17. Ter-Avanesyan MD, Dagkesamanskaya AR, Kushnirov VV, Smirnov VN. The SUP35 omnipotent suppressor gene is involved in the maintenance of the non-Mendelian determinant [psi+] in the yeast Saccharomyces cerevisiae. Genetics. 1994,137(3):671-6.

18. Tuite MF. The natural history of yeast prions. In: Sariaslani S, Gadd GM, editors. Advances in Applied Microbiology. 1st ed. USA: Academic Press. 2013. 
19. Zhouravleva G, Frolova L, Goff XL, Guellec RL, Inge-Vechtomov S, Kisselev L, Philippe M. Termination of translation in eukaryotes is governed by two interacting polypeptide chain release factors, eRF1 and eRF3. EMBO J. 1995,14(16):4065-72.

20. Serio TR, Lindquist SL. [PSI+]: an epigenetic modulator of translation termination efficiency. Annu Rev Cell Dev Bi. 1999,15(1):661-703.

21. Derkatch IL, Chernoff YO, Kushnirov VV, Inge-Vechtomov SG, Liebman SW. Genesis and variability of [PSI] prion factors in Saccharomyces cerevisiae. Genetics. 1996,144(4):1375-86.

22. Xiao Y, Rocha S, Kitts CC, Reymer A, Beke-Somfai T, Frederick KK, Norden B. Michlers hydrol blue elucidates structural differences in prion strains. Proceedings of the National Academy of Sciences. 2020,117(47):29677-83.

23. Liebman SW, Chernoff YO. Prions in Yeast. Genetics. 2012,191(4):1041-72.

24. Bradley ME, Edskes HK, Hong JY, Wickner RB, Liebman SW. Interactions among prions and prion “strains" in yeast. P Nat Acad Sci. 2002,99(Supplement 4):16392-9.

25. Chernova TA, Chernoff YO, Wilkinson KD. Yeast models for amyloids and prions: Environmental modulation and drug discovery. Molecules. 2019,24(18):3388.

26. Glover JR, Lindquist S. Hsp104, Hsp70, and Hsp40: a novel chaperone system that rescues previously aggregated proteins. Cell. 1998,94(1):73-82.

27. Jung G, Masison DC. Guanidine hydrochloride inhibits Hsp104 activity in vivo: a possible explanation for its effect in curing yeast prions. Curr Microbiol. 2001,43(1):7-10.

28. Jurgelevičiūtė J, Bičkovas N, Sakalauskas A, Novickij V, Smirnovas V, Lastauskienė E. Effects of pulsed electric fields on yeast with prions and the structure of amyloid fibrils. Applied sciences. 2021,11(6):2684.

29. Linden R, Martins VR, Prado MA, Cammarota M, Izquierdo I, Brentani RR. Physiology of the prion protein. Physiol Rev. 2008,88(2):673-728.

30. Guest WC, Cashman NR, Plotkin SS. Electrostatics in the stability and misfolding of the prion protein: salt bridges, self-energy, and solvation. Biochem Cell Biol. 2010, 88(2):371-81.

31. Estruch F. Stress-controlled transcription factors, stress-induced genes and stress tolerance in budding yeast. FEMS Microbiol Rev. 2000,24(4):469-86.

32. Uptain SM, Sawicki GJ, Caughey B, Lindquist S. Strains of [PSI+] are distinguished by their efficiencies of prion-mediated conformational conversion. The EMBO journal. 2001,20(22):6236-45.

33. Weaver JC. Electroporation: a general phenomenon for manipulating cells and tissues. Journal of cellular biochemistry. 1993,51(4):426-35.

34. Ghosh R, Dong J, Wall J, Frederick KK. Amyloid fibrils embodying distinctive yeast prion phenotypes exhibit diverse morphologies. FEMS yeast research. 2018,18(6):foy059.

35. Wickner RB, Shewmaker F, Edskes H, Kryndushkin D, Nemecek J, McGlinchey R, Bateman D, Winchester CL. Prion amyloid structure explains templating: how proteins can be genes. FEMS yeast research. 2010,10(8):980-91. 
36. Chernoff YO, Lindquist SL, Ono BI, Inge-Vechtomov SG, Liebman SW. Role of the chaperone protein Hsp104 in propagation of the yeast prion-like factor [psi+]. Science. 1995,268(5212):880-4.

37. Vandermeer J. How populations grow: the exponential and logistic equations. Nature Education Knowledge. 2010,3(10):15.

\section{Figures}

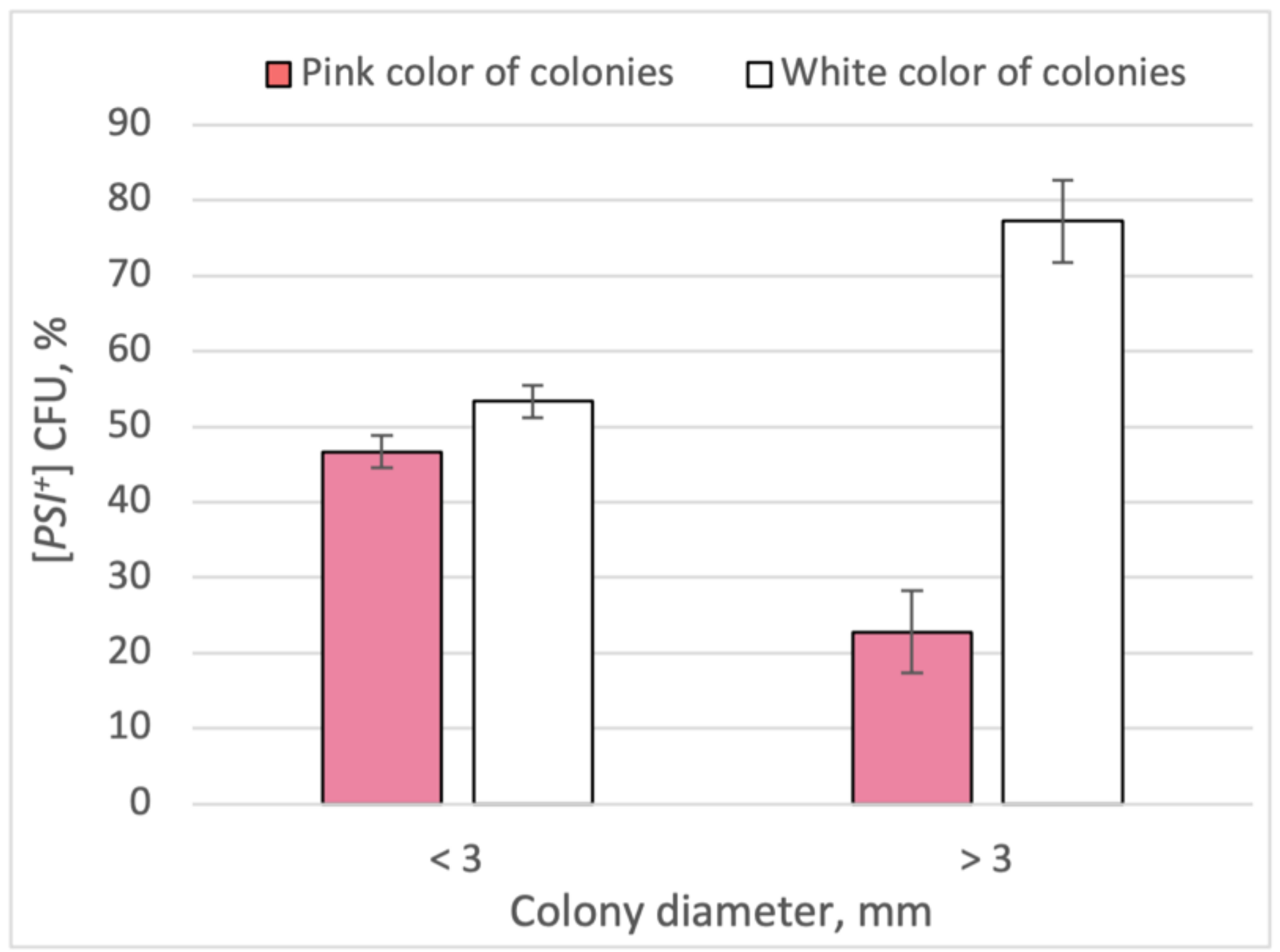

Figure 1

Distribution of the cells containing $\left[\mathrm{PSI}^{+}\right]$prion by colony color and colony diameter. $\mathrm{CFU}-$ colonies forming units. Data presented as average $\pm S E$. 


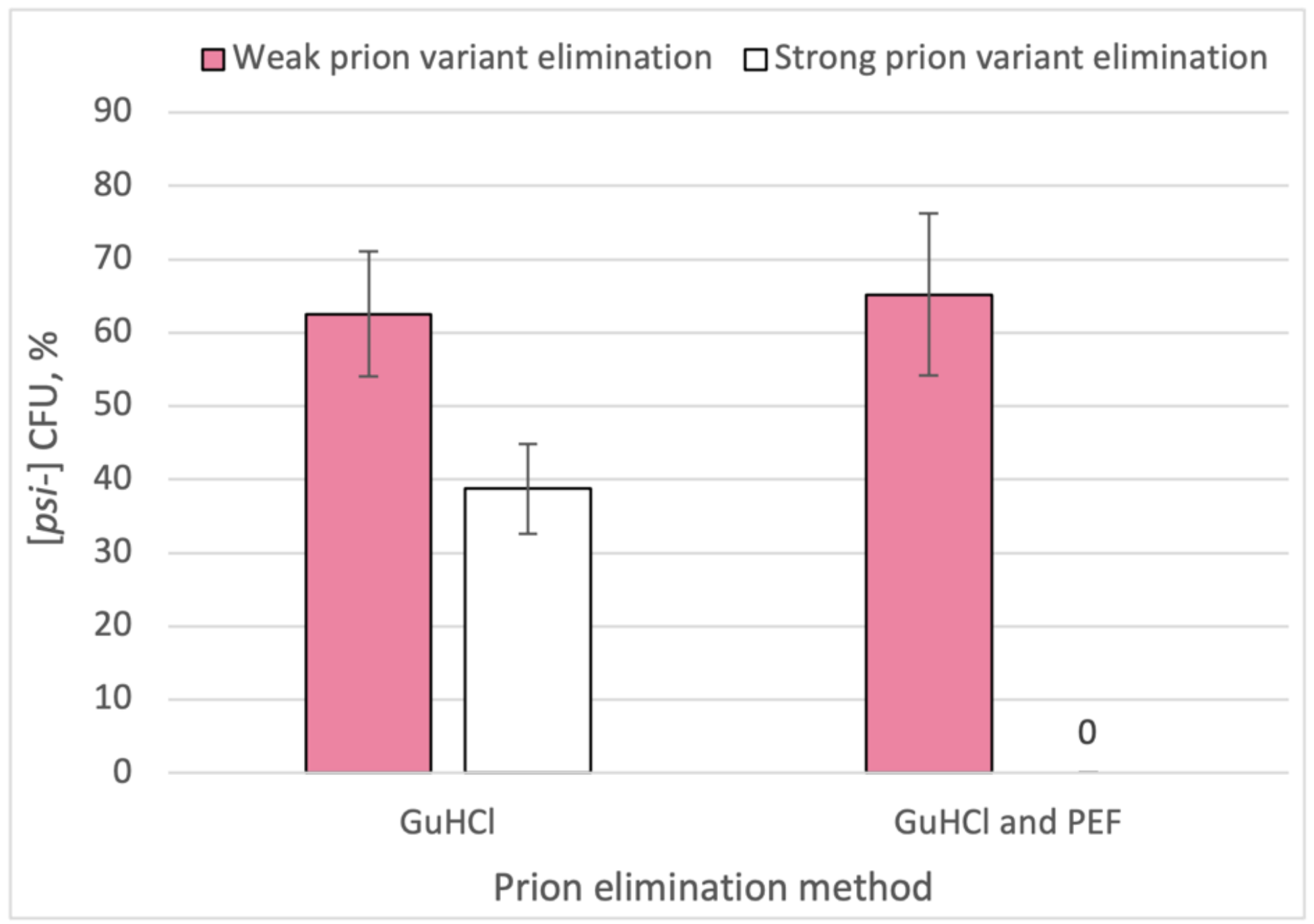

Figure 2

Percentage of the cells eliminated from the weak or strong $\left[P S I^{+}\right]$prion variant. $\mathrm{CFU}$ - colonies forming units, $\mathrm{GuHCl}$ - guanidine hydrochloride, PEF - pulsed electric field. Strong $\left[\mathrm{PSI}^{+}\right]$prion could not be eliminated using $\mathrm{GuHCl}$ and PEF. Data presented as average \pm SE. 


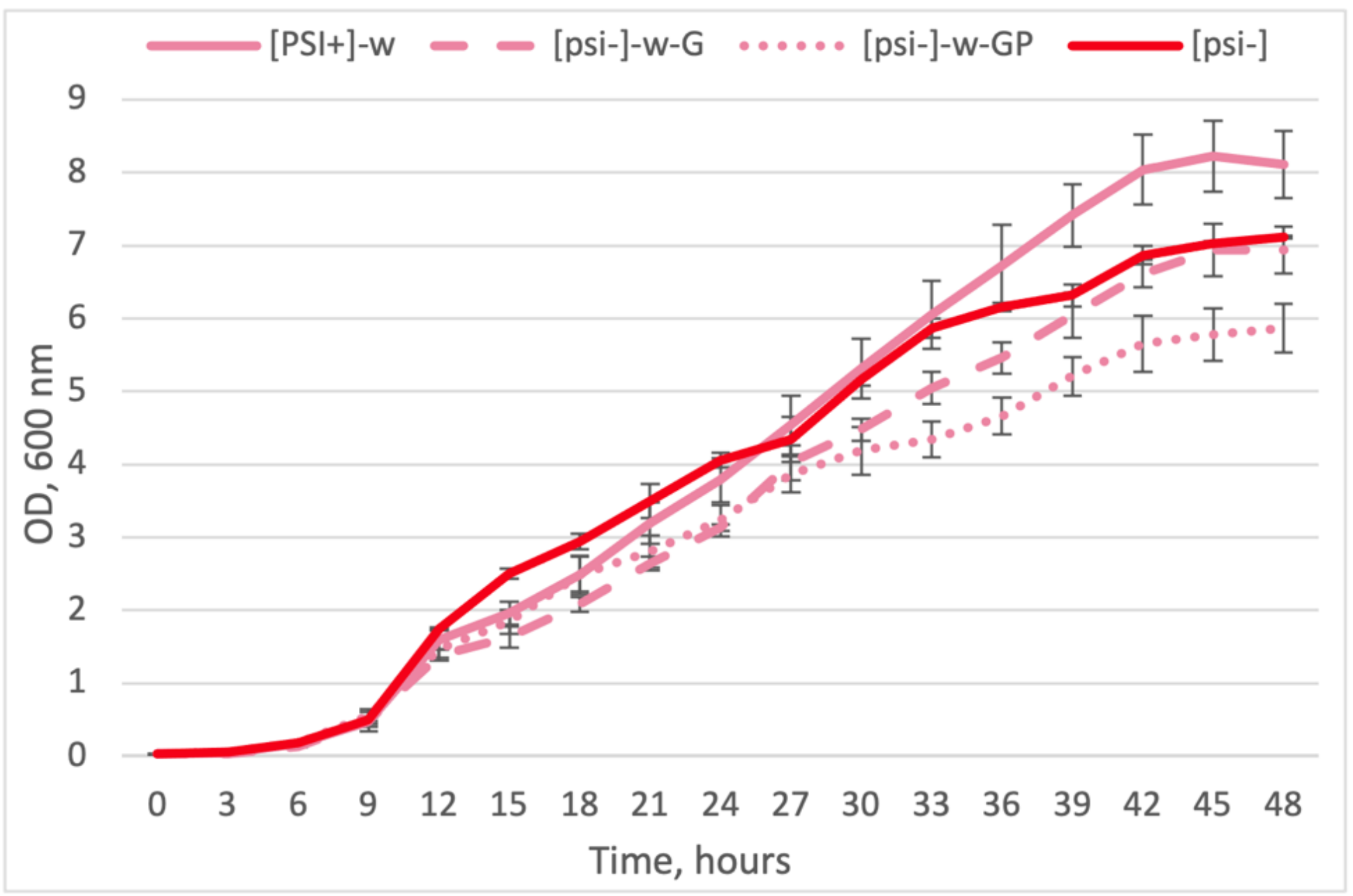

Figure 3

Growth dynamics of the cells with and without $\left[\mathrm{PSI}^{+}\right]$prion (weak variant). OD - optical density. Data presented as average \pm SE. 


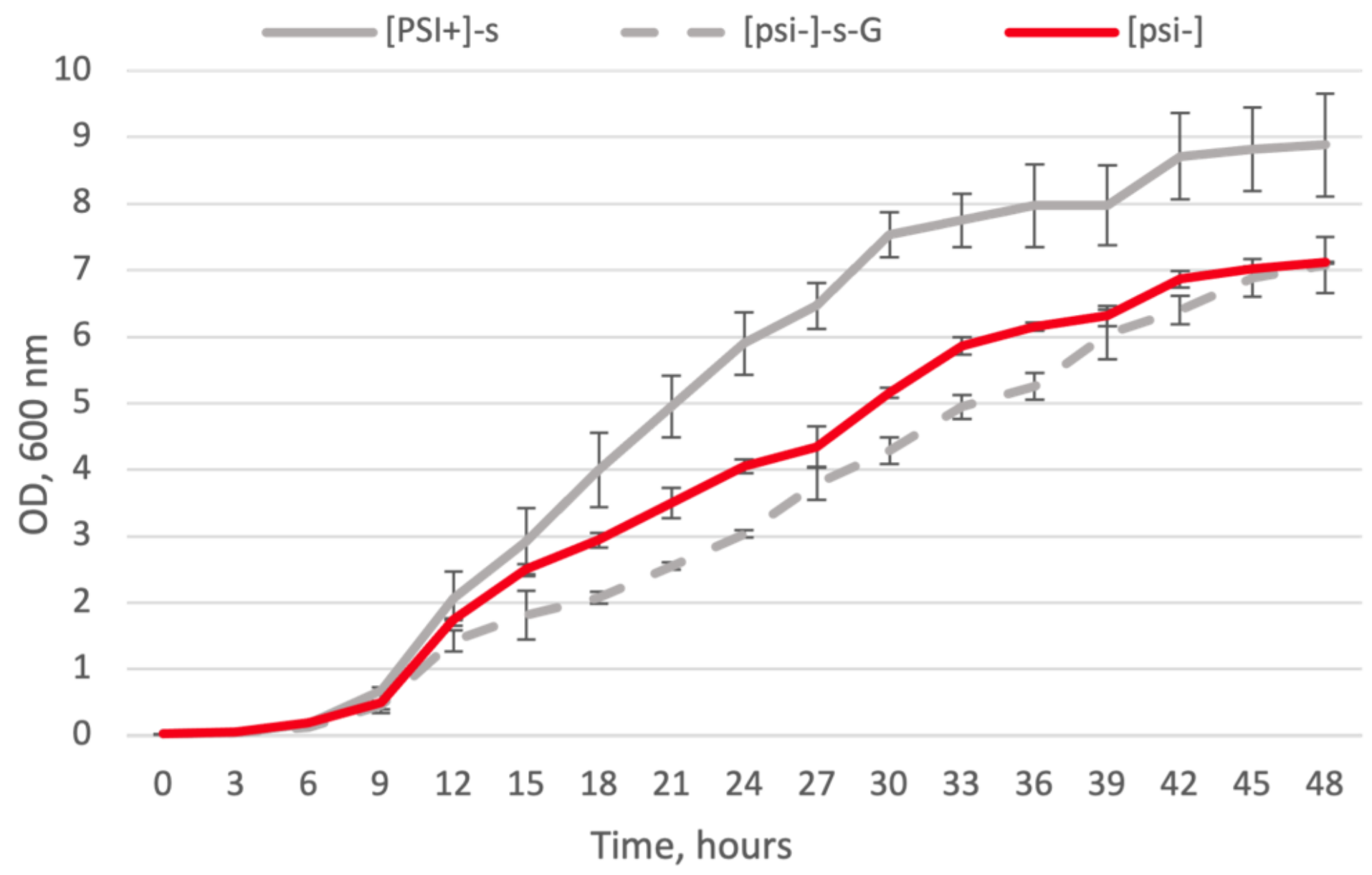

Figure 4

Growth dynamics of the cells with and without $\left[\mathrm{PSI}^{+}\right]$prion (strong variant). OD - optical density. Data presented as average \pm SE. 


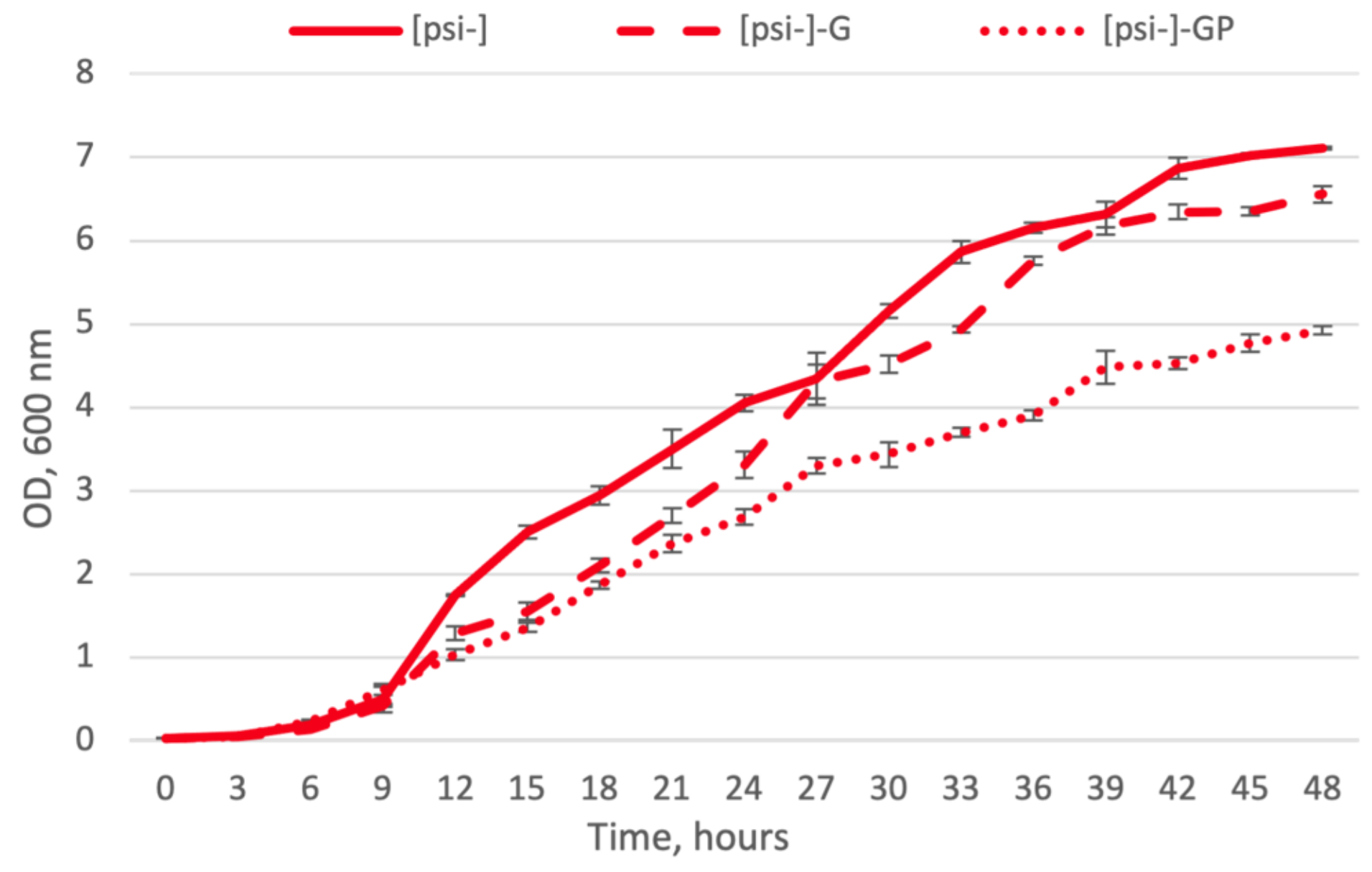

Figure 5

Growth dynamics of the cells without $\left[P S I^{+}\right]$prion and affected by different elimination methods. OD optical density. Data presented as average \pm SE. 

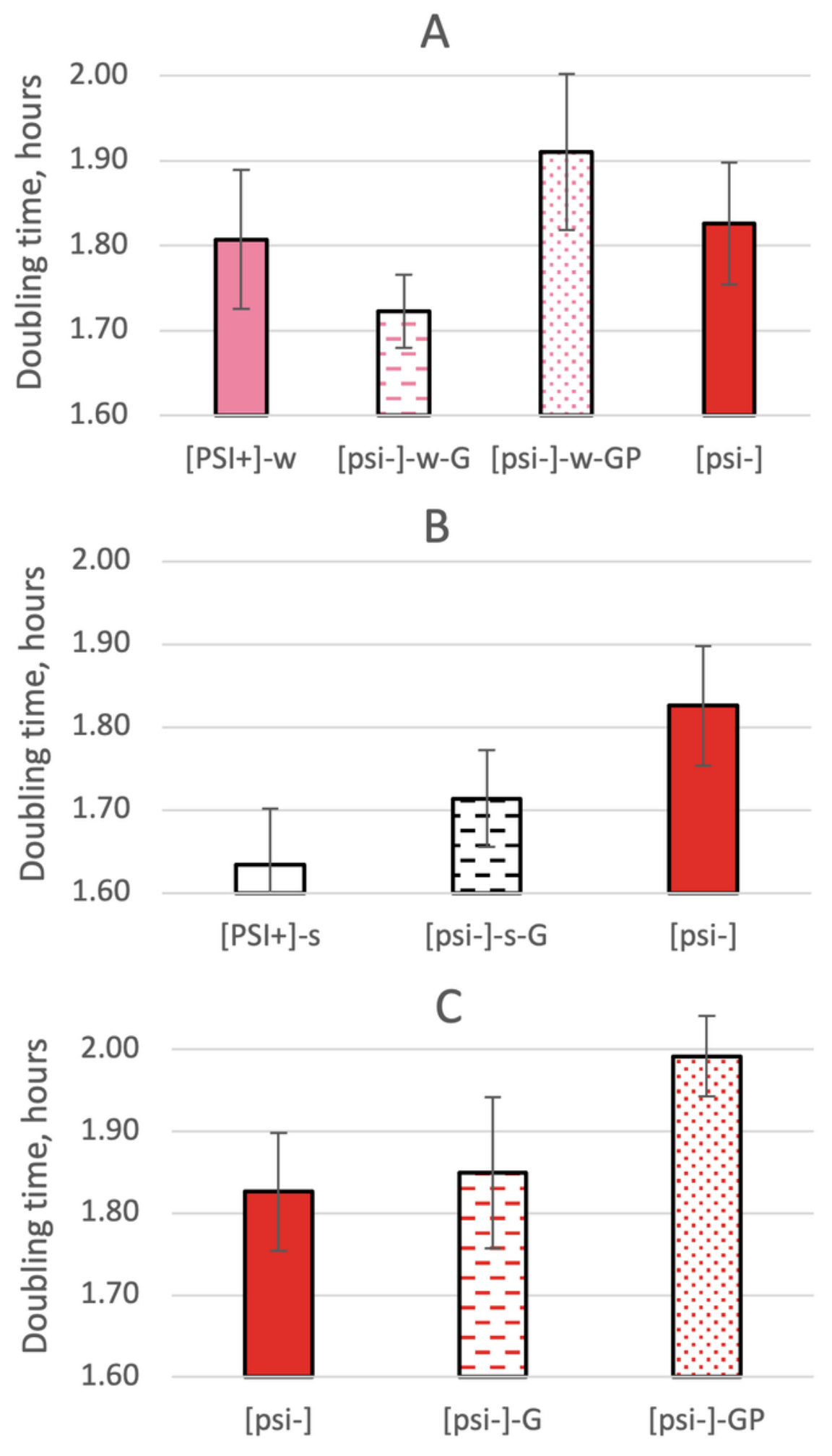

Figure 6

Doubling time of the cells with and without $\left[\mathrm{PSI}^{+}\right]$prion affected by different elimination methods. Data presented as average $\pm S E$. A - doubling time of the cells with and without $\left[P S I^{+}\right]$prion (weak variant). B doubling time of the cells with and without $\left[\mathrm{PSI}^{+}\right]$prion (strong variant). $\mathrm{C}$ - doubling time of the cells without $\left[P S I^{+}\right]$prion and affected by different elimination methods. 


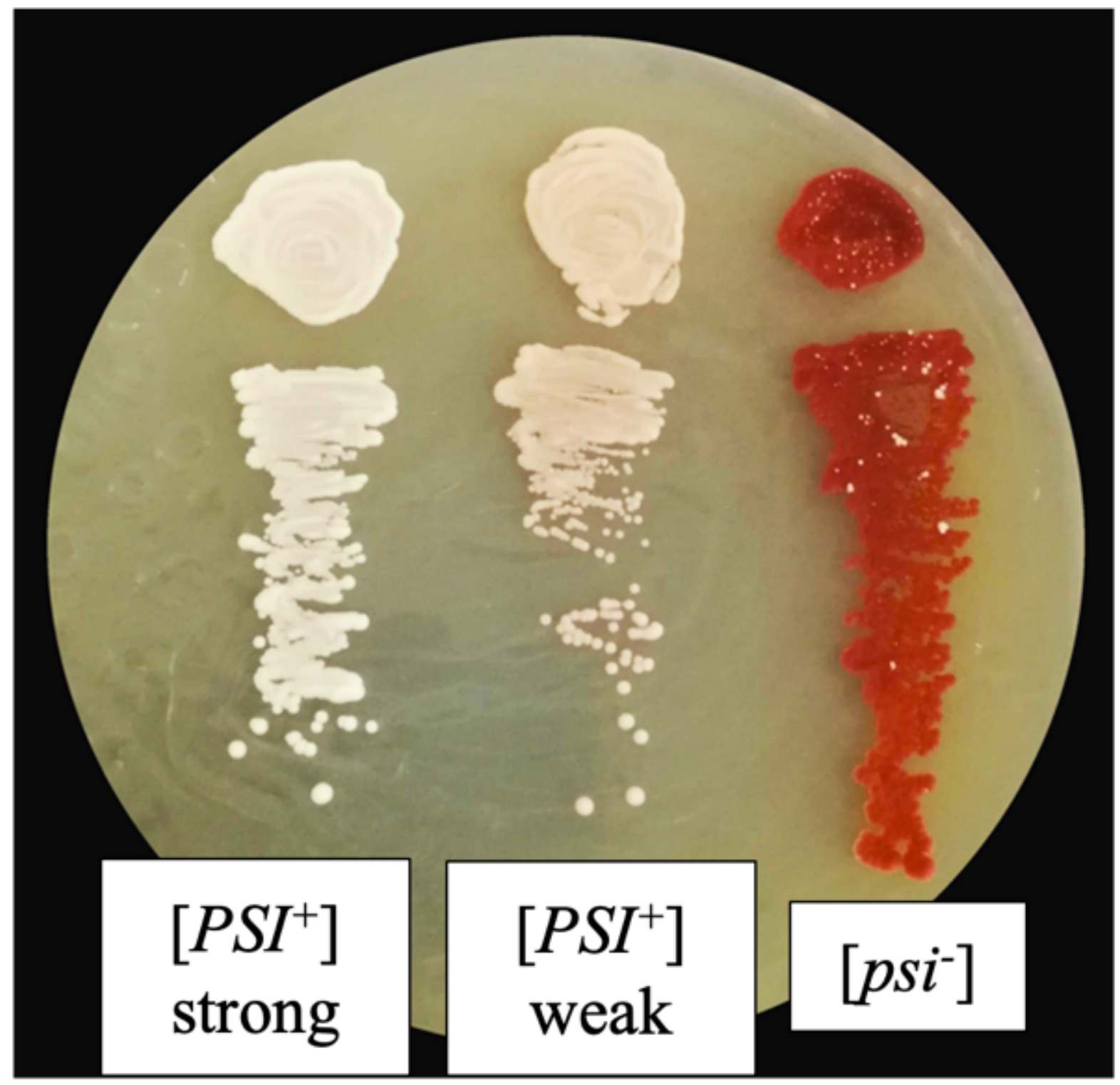

Figure 7

Phenotype of ADE1 mutants in an YPD medium. White-cells containing strong [PSI $\left.{ }^{+}\right]$prion, pink-cells containing weak $\left[\mathrm{PSI}^{+}\right]$prion, and red-cells without $\left[\mathrm{PSI}^{+}\right]$prion ([psi $]$).

\section{Supplementary Files}

This is a list of supplementary files associated with this preprint. Click to download.

- Additionalfile1.docx

- Additionalfile2.docx

- Additionalfile3.docx

- Additionalfile4.docx 